\title{
Article
}

\section{Steps on the Path Towards Decolonization: A Reflection on Learning, Experience, and Practice in Academic Support at the Uni- versity of Manitoba}

Monique Dumontet, Marion Kiprop, and Carla Loewen University of Manitoba

\section{Abstract}

This essay comes out of a panel presentation featured at the 2018 Canadian Association Writing Centres Conference entitled, "Steps on the Path of Decolonization" where representatives of the Academic Learning Centre and the Indigenous Student Centre from the University of Manitoba collaborated to discuss how our student support offices have made efforts at decolonizing our work. We three women of Canadian Settler, International, and Indigenous backgrounds reflect on how the journey on the path towards decolonization has been for us personally, and on how post-secondary institutions can move forward with the work of decolonization, particularly within Writing/Learning Centres. Key themes included the need for ongoing learning, the value of building collaborative relationships, and the importance of creating safe and inviting spaces. Our conclusions suggest that decolonization is a complex journey for individuals and for post-secondary institutions.

To begin in a good way, the writers would like to acknowledge that we work at the University of Manitoba, which is located on original lands of Anishinaabeg, Cree, Oji-Cree, Dakota, and Dene Peoples, and on the homeland of the Métis Nation.

\section{Introduction}

Recently, there has been an increased focus on Indigenous ${ }^{1}$ issues in Canadian higher education in general and at the University of Manitoba (UM) in particular. This increased attention may be due to a number of factors, including the release of the Final Report of the Truth and Reconciliation Commission (TRC) (December, 2015); the location of the National Centre for Truth and Reconcilia- 
Volume 29, 2019

http://journals.sfu.ca/cjsdw

tion on the UM campus (November 2015); the UM's ongoing commitment to Indigenous Achievement expressed in its Strategic Plan, “Taking Our Place” (2015-2020); and the numerous activities, events, projects, and programs linked to this Strategic Plan.

There is also a general acknowledgement of serious problems in Canadian education. In particular, the current education system, including post-secondary education, continues to be Eurocentric and assimilative. Post-secondary educational institutions are, therefore, still complicit in colonialism. The damaging effects of colonialism are evident everywhere, including student performance.

Indigenous students do not reach the same educational achievements as their nonIndigenous peers. For instance, Chelsea Vowel (2016) noted that "10\% of the Indigenous population have a university degree compared to $26 \%$ among non-Indigenous students". Gaps in educational attainment stem from well-documented institutional and cultural barriers, as well as marginalization (Hardes, 2006; Holmes; 2006, Preston; 2008). Non-Indigenous students also suffer the negative effects of on-going colonialism. For example, they rarely learn about Indigenous peoples, histories, cultures, languages, and ways of knowing (Calderon, 2011; Battiste, 2008; Schaefli et al., 2018).

This article will discuss and interrogate some of the ways the UM's Academic Learning Centre (ALC) has and might continue to move forward on a path towards decolonization by working individually to increase our knowledge and deepen our understanding, and by working with campus partners, especially the Indigenous Student Centre (ISC). Our goal is to provide better student support-both for those who are Indigenous and those who are non-Indigenous-with the ultimate aim of reconciliation. The catalyst for this article was the Canadian Writing Centres Association / l'Association Canadienne Des Centres de Rédaction conference, held May 23 to May 25, 2018, at the University of Saskatchewan in Saskatoon. All three of us attended the conference, the theme of which was "Politics and the Writing Centre: Inquiry, Knowledge, Dialogue and Action." We presented as a panel discussion with a focus on decolonization. Key themes that emerged were about the need for

- on-going learning

- building collaborative relationships

- creating safe and inviting spaces

Ultimately, we concluded that decolonization is a complex and multifaceted process that is best conceived as a journey rather than a destination. To explain the conception of the journey, we refer to the Medicine Wheel. According to Majore (2013), the Medicine Wheel is a holistic model that 
Volume 29, 2019

http://journals.sfu.ca/cjsdw

guides us on a journey towards healing and decolonization. Just as the Medicine Wheel is "whole and never ending" (Ambridge et al., 2012, p. 4), decolonization is a process that is never ending. The idea of decolonization as a journey also allows for individual progress and responsibility, as well as institutional movement and systemic change. Finally, the journey metaphor matches our approach because auto-ethnography focuses on processes as much as on the results or conclusions.

\section{Approach}

We employed an auto-ethnographic approach—an approach developed at a "moment in the history of qualitative research, in which participatory research and experimental writing feature more strongly" (Duncan, 2004, p. 30). Auto-ethnography is rooted in ethnography-a fieldwork technique that entails immersing oneself with the research community, learning the research community's language, and participating as an active observer in the daily activities of the research group (Duncan, 2004). In an auto-ethnography, the researcher is the subject, and the subject is the researcher. This approach calls for critical reflection, given the degree of self-implication in this kind of study.

Auto-ethnography made sense for the purpose that guided our team while preparing for the conference and this article: to reflect on our subjective experiences while fulfilling different roles in student academic support at the UM, a Western-oriented institution. Collaborating on different projects aimed at increasing Indigenous students' access to various academic and learning support resources at the UM, our team has had discussions about the value of reflective practice in ensuring that our interactions with Indigenous students are founded on the principles of reconciliation and decolonization. The value of auto-ethnography (and narrative auto-ethnography in particular) lies in reflecting on our practice, sharing our experiences with peers and colleagues, and identifying best practices.

Banks and Banks (2000) suggest that the process of critical reflection involves the examination of "asymmetries of power, unequal opportunities to render judgments, and mal-distributions of responsibility and rewards in our institutional lives, perhaps to help us better recognize the obstacles to creating more effective communities" (p. 236). As critical reflective practitioners who are taking steps towards decolonization in our various student academic learning and support roles, we explored a shared set of questions:

- How do we explain our positionalities?

- How do we understand decolonization? 
Volume 29, 2019

http://journals.sfu.ca/cjsdw

- How do we, as representatives of the academy, practice decolonization?

\section{Definitions of Decolonization}

Scholarly definitions of decolonization in a North American context continue to develop and evolve, but they typically discuss

- critical consciousness and understanding of the effects of colonization

- reflection and action leading to change

- challenging/resisting/overturning the forces of colonialism, including institutions and ideologies

- restoring cultural practices, ways of thinking, beliefs, and values

- advancement and empowerment of Indigenous peoples

Decolonization bears similarities to other related terms and ideas, including anti-racism and social justice movements or theories. For example, Nakata et al. (2012) argue that "anti-colonial critique is a fundamental beginning point for unsettling [...] presuppositions about IndigenousWestern relations" (p. 121). They also contend that decolonization aligns "with the liberal inclusionary politics of the social justice framework" (p. 123). For Nakata et al., however, social justice theory's critique of the Western is insufficient and "runs the danger of reifying the colonial binaries" (p. 127). Tuck and Yang (2012) go further, asserting that the pursuit of social justice may be merely a "move to settler innocence" or something akin to "settler harm reduction." The pursuit of social justice is only a stopgap; it may be profoundly essential, but it is not necessarily, or inherently decolonizing.

Decolonization is also related to post-modern ideas about overturning hierarchies, moving from rigid binaries to conceptions of "both/and," and resisting traditional academic notions of neutral, objective observers. Likewise, decolonization is aligned with post-colonial theories, particularly because both terms imply the rejection or reversal of colonization. Post-colonialism, however, is less specific, or broader in scope than decolonization. In addition, post-colonialism is often preoccupied with questions about hybridity and Otherness that are typically absent from discussions around decolonization. And, because the colonizers have not left, post-colonial theory is not a good fit in situations of settler-colonialism, like Canada. Ultimately, despite some ostensible alignment, post-colonialism differs from decolonization in focus and context. 
Volume 29, 2019

http://journals.sfu.ca/cjsdw

Decolonization, Indigenization, and reconciliation are closely associated terms-even sometimes used interchangeably. Bopp, Brown and Robb (2017) define Indigenization as "the process of creating a supportive and comfortable space inside our institutions within which Indigenous people can succeed." Nakata et al. (2012) argue that decolonization, not Indigenization, is the more desirable outcome because decolonization opens more possibilities and because decolonization ultimately serves Indigenous needs better. They prefer the term "decolonizing" over "Indigenizing" because it means the unseating of Eurocentric paradigms, cultural messages, and institutional practices, rather than simply adding something to the status quo.

Within educational institutions, particularly post-secondary contexts, decolonization has been defined as "the process of undoing colonizing practices [...] confronting and challenging the colonizing practices that have influenced education in the past, and which are still present today" (University of Victoria, n.d.). More practically, Battiste (2013) explains that decolonizing education entails reflecting on actions, curriculum and structures of educational institutions; confronting power relations, particularly in regards to control of knowledge; learning how to be an ally and working in solidarity; and adopting strength-based, holistic approaches.

\section{Indigenous Populations in Canada}

As we understand that decolonization is necessarily local and specific, some statistics will help locate where our path towards decolonization begins. The 2016 Canadian Census showed there are more than 1.6 million Indigenous people in Canada and estimated that that number will grow to over 2 million by 2036 (Aboriginal Peoples Highlight Tables, 2016). In Manitoba, 223,310 Indigenous people made up $18.0 \%$ of the population (Statistics Canada, 2017). It was also reported that the Indigenous youth population is younger the non-Indigenous population, particularly within the ages of 15 to 24 that represents $18.2 \%$ of the total Indigenous population. The youngest populations were reported in Manitoba and Saskatchewan. Statistics Canada also predicts that Indigenous peoples will comprise nearly 19 percent of Manitoba's population by 2026. In Winnipeg, Manitoba, $11 \%$ of the population was Indigenous in 2016. These statistics are important to note because, with this large Indigenous youth population, there could be more Indigenous students than ever entering university over the next few years. 
Volume 29, 2019

http://journals.sfu.ca/cjsdw

\section{Institutional Demographics and Student Supports for Indigenous Stu- dents at UM}

The UM is a research university and a member of the U15, with 29,563 students. Of these, 3,678 are pursuing a graduate degree (Office of Institutional Analysis, 2018). In 2017-18, there were 2,455 self-declared First Nations, Métis, and Inuit students. Of these students, 90.5\% are pursuing undergraduate degrees, and the most significant proportion of Indigenous students are enrolled in University 1, the Faculty of Arts, and the Faculty of Science (Office of Institutional Analysis, 2017). The UM offers a number of supports and services aimed at the Indigenous student population. Examples of programming at the ISC include Elders-in-Residence, the Qualico Bridge to Success (QBTS) program, a financial wellness program, a leadership program, a reading specialist, in-house counselling/student advocacy/career services, and cultural events.

\section{The Academic Learning Centre}

The UM's ALC is structurally located within Student Engagement and Success, which reports to the Vice-Provost (Students). The ALC has six full-time, permanent instructors in addition to approximately 40 student staff (ALC Tutors and ALC Supplemental Instruction Leaders). The UM's ALC offers services and programs (including one-to-one tutoring in writing, study skills, and content; workshops; online resources; and Supplemental Instruction ${ }^{2}$ ) to support the development of students' academic skills in writing, learning, and research. The ALC is a well-known and well-used resource on campus, with more than 6,100 one-to-one tutoring appointments in 2018, in addition to multiple student contacts through group programming (workshops, classroom visits, and SI). The unit frequently collaborates with UM instructors, libraries, other student support units, departments, faculties, and programs.

The relationship between the ALC and the ISC is one of the most well-established collaborations amongst campus partners. Since 2011, an ALC Instructor has been located in Migizii Agamik - Bald Eagle Lodge, a building on the main UM campus that houses the ISC, as well as Access and Aboriginal Focus Programs, Indigenous Engagement offices, and the UM Indigenous Students' Association. Given the ALC's connections and established reputation on campus, as well as its reach with students, we believe the ALC can model decolonizing practices and potentially effect change within the UM and the larger community. 
Volume 29, 2019

http://journals.sfu.ca/cjsdw

\section{Monique}

My name is Monique Dumontet. I am a non-Indigenous person living in Canada. Or, to use Chelsea Vowel's (2016) suggested terminology, I am a member of the "European-descended sociopolitical majority." I am a settler. My journey on the path towards decolonization began with some of my earliest post-secondary teaching experiences when I taught Indigenous students in the Northern Manitoba communities of Thompson, Norway House, Pimicikamāk (Cross Lake), and Nisichawayasihk Cree Nation (Nelson House). I was acutely aware of my identity as a settler for the first time when I stood in front of a class of Cree students to teach academic writing. In this reflection, the key themes that emerge are individual responsibility, on-going learning, building relationships, and creating safe spaces.

I feel strongly that it is my responsibility to take an active role in reconciliation and decolonization. This responsibility is mine in part because I am an educator at a Canadian university. Historically, universities played a role in colonization; Canadian post-secondary institutions are "deeply rooted in processes of settler colonialism" (Peace, 2016). UM President and Vice-Chancellor David Barnard (2011) outlined some of the specific ways the UM played a role in colonization in the University of Manitoba Statement of Apology and Reconciliation to Indian Residential School Survivors. In particular, he identified the UM's failure to "recognize or challenge the forced assimilation of Aboriginal peoples and the subsequent loss of their language, culture and traditions". He also noted the UM's indirect contribution to colonization as educators of "clergy, teachers, social workers, civil servants and politicians" - those who designed and implemented assimilation policies including the Indian Residential School system and the 60s Scoop (Barnard, 2011). Barnard apologized on behalf of the UM, for the harms suffered by First Nations, Métis, and Inuit communities, students, and staff. As a settler Canadian member of the UM community, I am called on to fulfill the statement's promises to work to restore trust and to nurture "healing and reconciliation" (Barnard, 2011).

This sense of responsibility also falls to me because the existence of colonization is often unrecognized by those like me-settler Canadians-who advantage from it. As a settler Canadian, I benefit from unearned advantages or privileges. The notion of invisible privileges is most famously framed in Peggy McIntosh's 1988 essay, "White Privilege and Male Privilege: A Personal Account of Coming to See Correspondences Through Work in Women's Studies." McIntosh (1988) described white privilege as an invisible set of unearned assets and provided a checklist of social privileges. For instance, in a Canadian post-secondary setting, I benefit from a Eurocentric curriculum that re- 
Volume 29, 2019

http://journals.sfu.ca/cjsdw

flects my identity, the ability to move through public spaces without harassment by security or police, and from the fact that most students, professors, and hiring committee members look like me. While acknowledging that McIntosh's model of privilege is perhaps too simplistic, particularly because it overlooks intersectional identities, her model helps to reveal the persistence of deep, unequal power relations. From my privileged position, I want to take actions related to how I take up space, work with others, and challenge systemic inequities with the aim of working towards decolonization and reconciliation.

As Bopp, Brown and Robb (2017) state, "Fundamentally, reconciliation is about healing our relationships, and that means all of us. We are all treaty people" (p. 5). Similarly, in the preface to the Final Report of the Truth and Reconciliation Commission of Canada (TRC), Murray Sinclair declares that "reconciliation is not an Aboriginal problem; it is a Canadian one." As an educator at the UM and as a settler-Canadian, decolonization is my responsibility. For me, decolonization starts with unpacking my privilege and undoing colonization by unlearning what I have been taught, including myths and stereotypes about Indigenous peoples. Continually educating myself on Indigenous issues, developing a critical consciousness, and understanding of colonization with the aim of effecting change are how I start on the path towards decolonization.

In addition to personal responsibility and on-going learning, the importance of building and maintaining relationships is another key theme that has emerged in my reflection. The ALC has a well-established partnership with the ISC. The funding arrangements, the hours, and the ALC staff working in Migizii Agamik have changed over the years, but there has been a collaborative relationship in place since 2009. An ALC Instructor has been located in Migizii Agamik full-time since 2014, offering one-to-one support and group programming. This partnership has led to co-delivered presentations, such as when an ALC instructor and/or ALC tutors present workshops to Indigenous student groups at Migizii Agamik with the Indigenous Liaison Librarian. Perhaps more importantly, the ALC/ISC partnership also leads to numerous "warm referrals" between ISC academic advisors, Elders-in-residence, personal counsellors, and the ALC Instructor / ALC Tutors. A "warm referral" occurs when a UM support provider introduces a student they are working with to another support provider directly (often in-person, but sometimes on the phone) and immediately, to ensure that the student is connected to someone who can provide what they need. I have observed that warm referrals are relationship-based and are more likely to result in successful engagement and retention. This is in contrast to cold referrals in which a student is merely given the name and number of another complimentary support provider and sent away. The ALC builds and maintains the rela- 
Volume 29, 2019

http://journals.sfu.ca/cjsdw

tionships that allow for warm referrals by showing up and participating in ISC and larger UM Indigenous community events, celebrations, and ceremonies.

The importance of creating a safe and inviting space for Indigenous students also emerged as a key theme in my reflection, particularly as I considered some of the practical goals and actions undertaken as part of deliberate efforts to decolonize. For example, deliberate efforts have been made to make ALC hiring practices part of our decolonization project. It has always been important that there be a strong representation of students who self-identify as Indigenous among the ALC Tutors hired to work at Migizii Agamik. Job postings for ALC student staff positions at Migizii Agamik have always included a particular invitation to Indigenous applicants, who are "strongly encouraged to apply." The job posting has also included "experience, knowledge and/or understanding of Indigenous cultures and histories" as a desirable asset among applicants. Recently, the ALC added a "strongly encouraged to apply" invitation to Indigenous applicants on all ALC student-staff job postings, including all ALC tutoring positions in all locations and ALC Supplemental Instruction (SI) Leader job postings, not just those who will work primarily in Migizii Agamik. Future plans related to ALC hiring practices include engaging more with Indigenous student groups on campus when recruiting, making the jobs more attractive by improving and communicating the experiential outcomes.

Increasing Indigenous cultural competency through professional development and training is another way to create safe and inviting spaces for Indigenous students, thereby moving forward on the path towards decolonization. The UM has provided opportunities for ALC Instructors to participate in various professional development activities to increase Indigenous awareness. ALC Instructors have been encouraged to participate in at least one Indigenous-focused professional development activity each term. In addition, professional development has been incorporated into regular staff meetings to increase the ALC's cultural competency. In future, the ALC might encourage more Indigenous-focused professional development by taking a broader view of PD. For example, attending ceremony could be equally valued as are attendance at academic conferences and participation in professional development programs or sessions offered by the institution. In doing so, the ALC and the UM would recognize and support the collaborative relationships necessary for decolonization. Similarly, as an assertion that developing and growing an understanding of Indigenous knowledge and practices are a priority, ALC Instructors' Annual Performance Reviews might include increasing Indigenous cultural competency goals. ALC Instructors could be encouraged and supported in taking on service activities that build Indigenous cultural competencies. 
Volume 29, 2019

http://journals.sfu.ca/cjsdw

Training for ALC student staff also aims to decolonize by increasing Indigenous cultural competency and creating safe spaces. In particular, ALC student staff training now includes an Indigenous cultural awareness module for all ALC Tutors and SI Leaders, not just those who tutor at Migizii Agamik. In future, the ALC might create additional training for its student staff, including independent, online, or blended-learning modules related to Indigenous cultural awareness.

The role of ALC Instructors in ARTS 1110 classrooms offers additional opportunities for creating safe spaces and taking steps towards decolonization. ALC Instructors began teaching sections of the for-credit UM course, ARTS 1110, "Introduction to University" (academic writing, learning, and critical thinking) in fall 2016. In our course teaching roles, ALC Instructors can influence course content, by including territorial acknowledgements in the classroom, by assigning essay topics that address emerging local Indigenous issues, and by using Indigenous epistemologies. ALC instructors also teach and support the Qualico Bridge to Success Indigenous-student cohort-a group of selfidentified Indigenous students who all register for a particular lecture and lab section of ARTS 1110 together. In future, the ALC could build and/or maintain academic programming partnerships between ALC Instructors and the ARTS 1110 QBTS cohort, with the QBTS Reading Specialist, and with the new Blankstein Momentum Program (designed to increase retention of Indigenous students). There may also be opportunities in the future for the increased involvement of ALC Instructors in distance/online offering of ARTS 1110 in remote Northern communities.

There are several additional possible steps that the ALC might take to move forward on the path to decolonization. For example, we might consider changes to the ALC's Mission/Vision statement to include and highlight our engagement with the project of decolonization. We might also take steps to make the ALC's physical spaces more reflective of Indigenous peoples' histories, contributions, languages, and diversities by updating our signage, webpage, bulletin boards, and promotional materials. Of course, I acknowledge that these steps alone will not erase or undo the effects of colonization, nor will they dismantle the systemic barriers and obstacles that Indigenous students and colleagues face in post-secondary education. However, I do believe that the accumulation of such small steps might improve the experience of Indigenous individuals in the academy and be part of systemic change.

\section{Marion}


Volume 29, 2019

http://journals.sfu.ca/cjsdw

My name is Marion Kiprop. In talking about my positionality, I believe that it is important to trace my own growth in relation to how I engage with decolonization in the Canadian settler-colonial context. I am a Ph.D. candidate in Peace and Conflict Studies at the UM working on generational variations in the approach to conflict and conflict resolution in a rural community in Kenya. I was born and raised in post-colonial Kenyan society and attended Kenyan schools to the completion of my Bachelor's degree. The Kenyan educational system from pre- to post-secondary level is largely fashioned after the British model, which places value on scientific modes of knowledge production based on rationality, objectivity, and neutrality. It was only recently that I started experimenting with the ideas of subjectivity, value-laden research and rigorous reflexivity on one's positionality and role in knowledge production.

It was not until I moved to Winnipeg that I was introduced to the history of colonialism in Canada and the impact it has had and continues to have on Indigenous peoples. I had heard a little bit about Indigenous peoples in the US when I was pursuing my Master's degree in Florida but remained ignorant about other Indigenous populations in the world, including Canada. When I started my Ph.D. program, I became much more aware of the history of colonialism in Canada, thanks to the active community in Winnipeg that cares about the challenges facing Indigenous peoples and how the Canadian situation implicates all residents of Canada. I often heard the words "We are all Treaty People" and "We are on Indigenous territory." I heard about the Idle No More movement and the Red Dress project, but I remained uninvolved and uninterested with these issues as I figured that the history of Canada had nothing to do with me, as I was simply in Canada to pursue my education.

As I reflected on my disengagement, I thought about a Swahili aphorism about hospitality, particularly, the extent of hospitality when burdensome guests overstay their welcome and take advantage of their host without making any contributions: Treat your visitors as guests for two days; on the third day give them a hoe and show them the farm. Upon learning more about the history of Canada through my work and study, I have had to examine my role as an international student living on Indigenous territory. While I am not a settler per se, I think of my decision to materially take up residence in Canada for the last six years as a kind of settlement. Also, I think about the placebased responsibilities I might have to the Indigenous territory on which I currently reside, and on which the UM-my place of work and study—is situated. I do not want to be a burdensome guest on Indigenous land and to Indigenous communities who signed treaties with the government that made it possible for me to work and study in Canada. 
Volume 29, 2019

http://journals.sfu.ca/cjsdw

While at the UM, I have worked in different capacities in student academic support, first as a seminar leader for ARTS 1110: Introduction to University, then as a lead tutor and program assistant for the ALC tutoring program at Migizii Agamik. The ALC tutoring program at Migizii Agamik provides writing, content, and study skills tutoring and, while it is aimed at supporting Indigenous students, our schedule is open to all UM students. The ALC tutoring program at Migizii Agamik is the only location at the UM with content tutors for various courses such as Chemistry, Engineering, Math, Biology and study skills tutors who work with students on study strategies, such as goal setting, time management, preparing for exams, and other learning strategies.

As an ALC Tutor at Migizii Agamik, my approach to decolonization and my practice of decolonization is largely informed by my positionality as a Kenyan woman who grew up in a post-colonial society. I recognize that the decolonization project is different in different contexts. Because of the multifarious nature of decolonization, the definition that I find most applicable to my practice is offered by Sium, Desai, and Ritskes (2012) who view decolonization as a "tangible unknown" (p. 1) with diverse "desired outcomes that are located at multiple sites in multiple forms, represented by and reflected in Indigenous sovereignty over land and sea, as well as over ideas and epistemologies" (p. 2). Sium, Desai and Ritskes (2012) further noted that decolonization "leaves room for dialogue and for dissent, as well as for coming together to each contribute to one another's shared visions and goals" (p. 12). This process requires not only working with others to contribute to shared goals, but also courageously taking responsibility for one's self-implicating actions.

For my tutoring practice, I engage with the ideas of decolonization by recognizing and affirming everyday acts of resurgence or what Sium, Desai and Ritskes (2012) call "local moments for decolonization" (p.1). I am going to give two examples of these local moments. First, I worked with an international student on various writing assignments over a year, some touching on the history of Canada and the Indigenous peoples of Canada. The tutee, during our earlier tutoring meetings, made non-harmful comparisons about the suffering of Indigenous peoples and the suffering of other minority groups around the world. As the term progressed and as the student learned more about Canadian history, I saw how this student went from categorizing herself as "not knowing much" about Canadian history to being a person seeking to be an activist for Indigenous rights. At the end of one of our tutoring sessions, the student made a comment about the importance of speaking up against the Canadian government's actions and the continuing structural inequality suffered by Indigenous people. She said, "If they can do this to Indigenous people on their own land, can you imagine what they can do to me, an international student, a non-Canadian?" This student's 
Volume 29, 2019

http://journals.sfu.ca/cjsdw

growth and development, to me, is what decolonization looks like: a process of learning new truths and unlearning prejudiced ideologies and thinking patterns. Decolonization, in my case, entails creating a safe space for student learning, for making mistakes, and for growth without judgement. This safe space allows students to trust that they are supported in their learning, which is always developmental.

The second example exemplifies the role of tutor as learner. I worked with a student who was writing about the Indian Act of 1876 and gender discrimination. This was the first time I had heard about Indigenous peoples losing their status. I humbly shared with the student that I was not familiar with the Indian Act and asked her if she would be willing to explain briefly what losing status meant. Immediately, I saw the student's eyes light up as she explained in detail the Indian Act and the subsequent modification in Bill C-31. I could tell that the student's excitement arose from my admission to my ignorance and from her recognition of her emerging expertise in the topic. The student continued to see me throughout the term, and during our sessions, I got to share details about my background and the colonial history of Kenya. From my interactions with this student, I learned that the sharing of personal geographies with students helps build relationships. Decolonization, thus, is also about building collaborations, sharing cross-geographical experiences, and finding ways to collaborate as we work towards finding and reflecting on these moments of decolonization.

\section{Carla}

My name is Carla Loewen, and I have worked at the UM since 2005, first with the University 1 First Year Centre and have been at the Indigenous Student Centre since 2015. Before that, I was a student three-times over, most recently completing my Masters in Education with a focus on Indigenous student success (Loewen, 2016). Through personal experience and research, I understand the common challenges facing Indigenous students and see students navigating these challenges every day.

My main challenge in university was learning how to make sense of my Indigenous identity. My biological family is Cree from Pukatawagan, Manitoba. I was adopted as a baby, and the family who raised me are non-Indigenous from Steinbach, Manitoba and in this way, I grew up in a colonized environment and continue to de-colonize myself on a daily basis. Growing up, I was given the time to learn my cultural roots at my own pace but did not begin to explore my Cree identity until I reached university. Being "Native / Aboriginal / Indigenous" was not something I identified with 
Volume 29, 2019

http://journals.sfu.ca/cjsdw

during my secondary school days. Not growing up in my culture also meant I had to learn about my Cree heritage alone, as I did not have any knowledge keepers to guide me. After I started studying at the UM, I was able to meet my biological family. It was a confusing time. I turned to my university for support by visiting the Aboriginal Student Centre, joining the UM's Aboriginal Students' Association and making my first Indigenous friends. While I became more comfortable in declaring my Cree heritage, I still felt like I did not quite fit into the role of Indigenous student. I certainly was not "non-Indigenous", but my lack of cultural or traditional knowledge made me feel like an outsider. I share this because everything I have learned about cultural and traditional knowledge has been through my university education.

Through a Cree language course and Native Studies courses from the introductory level to upper-level courses, I learned for the first time about the Indigenous history of Canada, including cultural information, political processes and Indigenous literature and more. In my work, I joined the Elders and Traditional Teachers Gathering planning committee and went to my first water ceremony and pipe ceremonies. I have been able to learn from Elders and cultural teachers and participate in cultural activities whenever I can. The first time I went sage picking on the land was a peaceful and beautiful learning experience. This kind of late identity journey is not uncommon for Indigenous students in post-secondary education.

The identity journey-learning about cultural roots, traditional practices and becoming comfortable in Indigenous student spaces-is a huge part of what many Indigenous students undergo during their post-secondary schooling. Restoule (2000) commented that many Indigenous students "are struggling with the creation of safe places to increase self-esteem and build understanding and acceptance of some of the Aboriginal cultural traditions" (p.106). In addition to struggling with identity issues, Indigenous students face other unique challenges.

Preston (2008) identifies five challenges that Indigenous people often face while acquiring postsecondary education. These are historical, educational, social, economic, geographical, cultural, pedagogical, and financial obstacles. Combined with the negative impact of colonialism, assimilationist policies, and residential schools, Indigenous people are still wary of education governed by policies that are not their own and were developed based on the belief in European superiority (Vickers, 2002). Students have parents and grandparents who attended residential schools; they come from urban and rural areas; they have families and struggle to make ends meet with the inefficiencies of band funding; and they come from schools that were unable to provide them with the resources needed to prepare adequately for post-secondary education. 
Volume 29, 2019

http://journals.sfu.ca/cjsdw

As part of my role as an Indigenous student advisor and program facilitator for first-year students, I work to support Indigenous students through their identity journeys and other challenges, while also connecting students with student services founded on Western worldviews and knowledge. Cull, Hancock, McKeown, Pidgeon and Vedan (2018) explain:

We work in systems that perpetuate colonial ideals and privilege Western ways of doing. For example, many student services use forms and procedures instead of first initiating relationships with students. This is a colonial process that excludes rather than includes. (p. 18)

I also take responsibility for students by acknowledging that post-secondary institutions were founded on colonial and hierarchical principles. I work to encourage students to view postsecondary education as a journey of accomplishment versus achievement. What defines success should not only be the celebration of high achievers, but also the recognition that success comes in a variety of outcomes. As stated by Brunette et al., "The university culture is widely known to be individualistic, competitive, and based on meritocracy. For some Indigenous peoples, these underlying norms can misalign with core values grounded in a sense of kinship, cooperation and relationships to family, community, and land" (n.d., p. 19). The following reflection will focus on how the ALC / ISC, as representatives of the academy, practice decolonization.

To help Indigenous students navigate their way through these cultural challenges and common challenges, the ISC, located in Migizii Agamik, offers a number of spiritual, physical, emotional, and mental supports and services. In particular, the ISC has an Elders-in-residence program, a men's group (Zongiigabowen), Full Moon Ceremonies, personal counselling, a traditional knowledge series called Fireside Chats, and a smudge-friendly space. The ISC also offers student advising, as well as financial wellness, leadership, peer mentor, transition, and retention programs. A Graduate Student Success Coordinator is located on-site. Staff from the UM's Student Advocacy, Career Services, and Libraries also visit regularly. Most important to this current discussion, an ALC Instructor, as well as ALC Content, Study Skills, and Writing Tutors are also located on-site.

Part of our effort to decolonize includes the partnership between the ALC / ISC. We collaborate and make a concentrated effort to offer meaningful programming to Indigenous students. By collaborating to support Indigenous student success, we are reconciling the harms of the past when Indigenous peoples were not allowed to obtain a degree, or if they did, were forced to forfeit their Indian status and when the residential school system was a tool of assimilation designed to eradicate languages and cultures. Our partnership is a critical response to a former education system that undermined and eliminated the Indigenous student. Furthermore, our partnership encourages 
Volume 29, 2019

http://journals.sfu.ca/cjsdw

us to continually re-think our work to improve the Indigenous student experience by creating safe spaces.

Building relationships with Indigenous students is also central to our shared work. To this end, the ALC was given space to have a full-time Instructor in Migizii Agamik, so that students have readily available writing and study skills support. Academic supports were enhanced by the creation of the UM's only free content tutoring program, staffed by ALC Tutors and located in Migizii Agamik. This partnership between the ISC and the ALC encourages relationships amongst ALC staff, ISC staff, and Indigenous students. Smith (2016) says that "Building relationships with Indigenous students is essential in working toward decolonization" (p. 54). I believe that having staff working together and alongside Indigenous students minimizes the hierarchy of expert teacher and novice student. Further, providing direct, on-site access to free ALC Tutors, makes it easier for Indigenous students to get academic support with tutors who are familiar with the students and the space.

A new initiative by the ALC and ISC involves offering a lab section of ARTS 1110: Introduction to University to Indigenous students in the Qualico Bridge to Success (QBTS) program. ARTS 1110 is a class designed to help students make the transition to university by imparting the knowledge, skills, and attitudes required for success in university study. The content of the QBTS lab section of ARTS 1110 is the same as all other sections, but only QBTS students can register. The benefit of the QBTS cohort section is that students get to learn with the same group of students throughout the term, and the ARTS 1110 instructor's office is on-site in Migizii Agamik. As the QBTS facilitator, I also visit the class periodically to connect with everyone and offer advising support. Similar to free on-site ALC tutoring, the ARTS 1110 QBTS cohort lab section aims to support Indigenous success and move us ahead on the path of decolonization.

Migizii Agamik Study Nights are another ALC / ISC partnership initiative designed to support Indigenous students and move us forward towards decolonization. Once a term, prior to final exams, the ISC hosts a study night where students eat, study and relax in the comfort of a group. ALC Tutors and an ALC Instructor are on hand throughout the evening. These initiatives are a collaborative approach and highlight our commitment to supporting Indigenous student success and decolonization.

To conclude, my journey on the path towards decolonization has included defining what decolonization means to me. I have also thought about how the ideologies of decolonization have influenced my work and how ALC / ISC collaborations contribute to decolonization. Decolonizing myself and my work is a lifelong journey. Whether through self-reflection or professional develop- 
Volume 29, 2019

http://journals.sfu.ca/cjsdw

ment, I will also seek new ways to improve my methods and approaches for supporting Indigenous student success. The importance of professional development is supported by Smith (2016), who said, "Professional development is a critical aspect of decolonizing education. In order for schools to be ready to support Indigenous students, staff must have an understanding of what they can do in their day to day practice" (p. 52).

\section{Conclusions and Recommendations}

Because decolonization begins with/as education, here are some of the readings and resources that we found useful and most directly relevant to post-secondary education, particularly academic learning / writing centres:

- The (2015) Truth and Reconciliation Commission Calls to Action provide clear direction on the path to reconciliation, with Calls to Action \#11, 16, 24, 62, 65, and 86 having the most direct relevance to post-secondary education.

- The (2016) Canadian Association of College and University Student Services (CACUSS) Student Affairs and Services Competency model includes a list of core Indigenous cultural awareness competencies for Student Affairs professionals.

- Marie Battiste’s (2008) essay, “The decolonization of aboriginal education: Dialogue, reflection, and action in Canada" recommends strategies for consciousness-raising "and collective action to transform theory and practice in education."

- Sheila Cote-Meek's (2014) book, Colonized Classrooms: Racism, Trauma and Resistance in Post-Secondary Education, illustrates how colonization and its violence are not a distant experience, but one that is being negotiated every day in universities and colleges across Canada.

- Chelsea Vowel's (2016) book Indigenous Writes: A Guide to First Nations, Métis and Inuit Issues in Canada is a collection of 31 essays organized around five broad, interrelated themes, including identity, myths, state violence, treaties, and laws.

To build and maintain the relationships that are so essential to decolonization, we recommend wide and varied collaboration, involving stakeholders at every level, from the student body to administrative leaders. To ensure continuity even in the face of individual staff changes, as much as possible these relationships should be formalized, through designated budget lines, official policies, workload assignments, and job position descriptions. 
Volume 29, 2019

http://journals.sfu.ca/cjsdw

Building relationships facilitates and supports the creation of safe spaces. Safe, inviting spaces are essential for student success, as well as for staff development. Creating safe spaces, especially physical spaces, is challenging, particularly because it often requires significant institutional commitments and investments. Smaller-scale and even notional safe-spaces are more possible. For example, we created (and required) a safe space when writing this article. We learned and journeyed together and solidified our relationships. This mindful reflection has strengthened our personal and professional commitment to decolonization. Finally, the three of us recognize that we must continue to examine our positionalities in order to decolonization ourselves while also building and maintaining our collaborative partnership between our units at the UM. By working both individually and collaboratively, we can continue our journey on a path towards decolonization. We hope our reflections encourage you to reflect on your own positionalities and to contribute to decolonization on your campuses.

\section{Endnotes}

1. Throughout this article, except when quoting sources or referring to historical documents, institutions, or policies, we will use the term "Indigenous" to refer specifically to First Nations, Inuit, and Métis peoples in Canada.

2. Supplemental Instruction, or SI, is an academic support program that offers free weekly review sessions to students in historically difficult classes. These voluntary sessions offer students an opportunity to discuss course content, ask questions, compare notes, solve practice problems, and develop study strategies. SI sessions are facilitated by a peer mentor who has previously taken the course.

\section{References}

Ambridge, S. et al. (2012). Full circle: First Nations, Métis and Inuit ways of knowing. Ontario Secondary School Teachers' Federation (OSSTF/FEESO). Retrieved from 1.

Banks, S., \& Banks, A. (2000). Reading "the critical life": Autoethnography as pedagogy. Communication Education, 49(3), 233-238.

Barnard, D.T. (2011). University of Manitoba Statement of Apology and Reconciliation to Indian Residential School Survivors. Retrieved from https://umanitoba.ca/about/media/StatementOfApology.pdf 
Volume 29, 2019

http://journals.sfu.ca/cjsdw

Battiste, M. (2008). The decolonization of aboriginal education: Dialogue, reflection, and action in Canada. In P. R. Dasen \& A. Akkari (Eds.), Educational Theories and Practices from the Majority World (pp. 168-195). New Delhi: SAGE Publications India Pvt Ltd. doi:

10.4135/9788132100683.n8Bopp, M., Brown, L., \& Robb, J. (2017). Reconciliation within the Academy: Why is Indigenization so Difficult? Retrieved from

http://www.fourworlds.ca/pdf downloads/Reconciliation within the Academy Final.pdf

Brunette, C., Richmond, C., Andersen, R., Baxter, J., Branfireun, B., Coward, D. Coyle, M., et al. (n.d.). Guide for Working with Indigenous Students. Western University. Retrieved from https://teaching.uwo.ca/pdf/teaching/Guide-for-Working-with-Indigenous-Students.pdf

Calderon, D. (2011). Locating the foundations of epistemologies of ignorance in education ideology and practice. In E. Malewski \& N. Jaramillo (Eds.), Epistemologies of Ignorance in Education. . New York, NY: Information Age Publishing. 105-127.

Cote-Meek, S. (2014). Colonized Classrooms: Racism, Trauma and Resistance in Post-Secondary Education. Black Point, NS: Fernwood Publishing.

Cull, I., Hancock, R., McKeown, S., Pidgeon, M., \& Vedan, A. (2018). Pulling Together: A Guide for Front-Line Staff, Student Services, and Advisors. Victoria: BCcampus, BC Open Textbook Project.

Duncan, M. (2004). Autoethnography: Critical appreciation of an emerging art. International Journal of Qualitative Methods, 3(4), 28-39.

Fernandez, D., Fitzgerald, C., Hambler P., \& Mason-Innes, T. (2016). Indigenous cultural awareness. CACUSS Student Affairs and Services Competency Model. Retrieved from https://carleton.ca/studentsupport/wpcontent/uploads/CACUSS Student Affairs and Services Competency Model FINAL.pdf

Hardes, J. (2006). Retention of aboriginal students in postsecondary education. Alberta Counsellor, 29(1), 28-33.

Holmes, D. (2006). Redressing the balance: Canadian university programs in support of aboriginal students. Ottawa, ON: Association of Universities and Colleges of Canada.

Loewen, C. M. (2016). Neechiwaken - Peer mentoring: Supporting aboriginal students in academic community (master's thesis). University of Manitoba, Canada. Retrieved from https://mspace.lib.umanitoba.ca/handle/1993/31244

Majore, D. (2013). Medicine wheel journey: An autobiographical approach to developing an Indigenous-centered helping framework. (master's thesis). University of Victoria, Victoria, BC. 
Volume 29, 2019

http://journals.sfu.ca/cjsdw

McIntosh, P. (1988). White Privilege and Male Privilege: A Personal Account of Coming to See Correspondences Through Work in Women's Studies. Wellesley, Mass: Center for Research on Women, Wellesley College.

Nakata, M., Nakata, V., Keech, S., \& Bolt, R. (2012). Decolonial goals and pedagogies for Indigenous studies. Decolonization: Indigeneity, Education \& Society, 1(1).

Office of Institutional Analysis (2017). Canadian Indigenous Students. Winnipeg, MB: University of Manitoba. Retrieved from http://umanitoba.ca/admin/oia/media/Canadian Indigenous Students F C S overall pop Indi genous Profile 17.pdf

Office of Institutional Analysis (2018). Preliminary Fall Term Enrolment Report. Winnipeg, MB:

University of Manitoba. Retrieved from http://umanitoba.ca/admin/oia/media/student enrol F18 ECC.pdf

Peace, T. (2016). Indigenous Peoples: A Starting Place for the History of Higher Education in Canada. Retrieved from http://activehistory.ca/2016/01/rethinking-higher-education-colonialismand-indigenous-peoples/

Restoule, J. (2000). Aboriginal Identity: The Need for Historical and Contextual Perspectives. Canadian Journal of Native Education, 24(2), 102-112.

Schaefli, L., Godlewska, A., Korteweg, L., Coombs, A., Morcom, L., \& Rose, J. (2018). What do firstyear university students in Ontario, Canada, know about First Nations, Métis, and Inuit peoples and topics? Canadian Journal of Education, 41(3), 688-725. Retrieved from http://journals.sfu.ca/cje/index.php/cje-rce/article/view/3247

Sium, A. Desai, C. \& Ritskes, E. (2012). Towards the 'tangible unknown': Decolonization and the Indigenous future. Decolonization: Indigeneity, Education \& Society, 1(1), i-xiii. Retrieved from https://jps.library.utoronto.ca/index.php/des/article/view/18638

Smith, T. (2016). Make space for indigeneity: Decolonizing education. Saskatchewan Education Leadership Unit Research Review Journal, 1(2), 49-59. Saskatoon, Saskatchewan.

Statistics Canada. (2016). Aboriginal Peoples Highlight Tables, 2016 Census. Ottawa, Ontario. Statistics Canada. Retrieved from https://www12.statcan.gc.ca/census-recensement/2016/dp$\mathrm{pd} /$ hlt-fst/abo-aut/Table.cfm?Lang=Eng\&T=101\&S=99\&O=A

Statistics Canada. (2017). Focus on Geography Series, 2016 Census. Statistics Canada Catalogue no. 98-404-X2016001. Ottawa, Ontario. Data products, 2016 Census. 
Volume 29, 2019

http://journals.sfu.ca/cjsdw

Truth and Reconciliation Commission of Canada: Calls to Action. 2015. Winnipeg, MB: Truth and Reconciliation Commission of Canada. Retrieved from http://www.trc.ca/websites/trcinstitution/File/2015/Findings/Calls to Action English2.pdf

Truth and Reconciliation Commission of Canada. (2015). What we have learned: Principles of truth and reconciliation. Library and Archives Canada Cataloguing in Publication. Retrieved from http://www.trc.ca/websites/trcinstitution/File/2015/Findings/Principles 20150531 web o. pdf

Tuck, E. \& Yang. K.W. (2012). Decolonization is not a metaphor. Decolonization: Indigeneity, Education \& Society, 1(1), 1-40. Retrieved from https://jps.library.utoronto.ca/index.php/des/article/view/18630

University of Victoria. (n.d.). Youth \& Society. Retrieved from https://www.uvic.ca/research/centres/youthsociety/assets/docs/briefs/decolonizingeducation-research-brief.pdf

Vickers, P. (2002). The colonial mind in post-secondary education. McGill Journal of Education, 37(2), 241-254. Retrieved from https://mje.mcgill.ca/article/view/8623/6566

Vowel, C. (2016). Indigenous Writes: A guide to First Nations Métis and Inuit Issues in Canada. Winnipeg, MB: Highwater Press. 